Acta Horticulturae et Regiotecturae 1

Nitra, Slovaca Universitas Agriculturae Nitriae, 2017, pp. 1-5

\title{
APPLICATION OF RAIN GARDENS TO AN URBAN AREA - HOUSING ESTATE IN NITRA, SLOVAKIA
}

\author{
Veronika VACULOVÁ*, Roberta ŠTĚPÁNKOVÁ \\ Slovak University of Agriculture in Nitra, Slovak Republic
}

\begin{abstract}
This study is focused on principles of rain gardens in landscape architecture and their application in Slovak conditions. Rain gardens can be seen as a part of sustainable design and application of ecological principles in changing natural conditions. The simplicity of a rain garden represents combination of rainwater management and flower planting, which is a strong landscaping element because of the connection between ecology and aesthetics. Plants used in rain gardens help to keep water by the root system and, after that, to transpire it. Another importance of this kind of arrangement is its simplicity and positive impact on creation of a new bio-retentive ecosystem, which is able to safely collect, absorb, filtrate and carry off rain water from paved areas. Many foreign countries have understood their importance and have already implemented them in new projects of public and private spaces. This paper also describes a theoretical planting proposal of a rain garden in a housing estate in the city of Nitra to demonstrate a real application of this technique in Slovak conditions.
\end{abstract}

Keywords: rain garden, sustainable design, water management, public space

The use of rain gardens and their practical application through landscape architecture is an issue of transformation of architects' and urbanists' thinking and their orientation towards sustainable design. During the rainy season, there is a large amount of water outflow through sewerage in areas with high proportion of hard surfaces or areas with extensive built-up surfaces. In this case, water is drained by pipe-lines to natural water systems (streams, rivers). As a consequence, it leads to water pollution and floods. Natural or planned (by spout pipes) alignment of water flow to rain gardens allows to relieve sewers, save funds, enhance the environment and make room for a new ecosystem. The plants (perennials, grasses, shrubs or small trees) allow the collection of storm water by their root system with consequential water transpiration. Plants act in simple and eco-friendly way in draining the excess of stormwater from hard surfaces. Similar principle is used in constructed wetlands that are used for treatment of the sewage wastewater (Fuska, 2009).

The city of Seattle (Washington, USA) is a good example of construction of rain gardens by providing a number of programs focused on stormwater management. The "Rain Wise Program" is centered on conscious water management, helps in planting and creating rain gardens etc. The "12,000 Rain Gardens" is a campaign led by the Washington State University and the Stewardship Partners with the aim of creating 12,000 rain gardens in Seattle by 2016. As a part of the project, there is a support for consultations, public awareness, workshops, volunteering and assistance, organising events and creating an online map allowing marking and monitoring the progress of emerging gardens (12000 raingardens.org, RainWise Program).

\section{Material and methods}

Materials for project development

- technical blueprints and situation plans of the studied area, digital format, system SJTSK;

- Landscape Atlas of the Slovak Republic [online]. Available at: <http://globus.sazp. sk/atlassr/>;

- data of average amount of rainfall totals in Nitra for 30 year time period (Source: Slovak Hydro-Meteorological Institute);

- soil maps [online]. Available at: <https://podnemapy.sk/> (Hraško et al., 1993).

\section{Rain gardens - principles and construction}

Rain gardens represent the natural water-absorbing elements with an aesthetic effect of flower bed planting. Rain gardens are terrain depressions planted with perennials and small shrubs or trees in the middle of which the root systems keep and consequentially transpire storm water. It is a bio-retention system that collects, absorbs, filtrates and safely drains away the excess of storm water of hard surfaces (Díaz Iglesias, 2013). In urban areas, the percentage of hard surfaces rates between $20 \%$ (in residential areas) to $85 \%$ in industrial areas (Novotny and Olem, 1994). There is about 9 times higher runoff from hard surfaces than it is in natural surfaces with the same area (Dane County Lakes and Watershed Commission). Laurenson and Arundell (2010) define a rain garden as a "water sensitive urban design".

The efficiency of water absorption is one of the main qualities; compared to grass surfaces, it is $30-40 \%$ higher. 
The stormwater includes various substances - chemicals, microbiological pathogens, soft sediments, phosphorus, nitrogen etc. According to Stiffler (2013), rain gardens act as a sponge because of water absorbing. The contaminated water substances are purified and eliminated by the rain garden plants. They also enrich underground waters; plants attract organisms and small animals, help to improve microclimatic conditions and to purify the environment (Tóth et al., 2015).

According to various authors, the rain garden establishment is possiblealmost anywhere. However, authors differ in their opinions on the distance of rain gardens from buildings; Hoffman and Orozco (2003) indicate 7.5 meters as the minimum. Other authors, publications and handbooks for USA set 3 meters as the minimum distance for simple buildings (Bannerman - Considine, Dane County Lakes and Watershed Commission) and 6 meters for basement buildings, while distance from roads is 1 meter (Rain-Garden Design and Implementation for Cansas Property Owners). It is important to take care of septic, engineering network and mature trees. A rain garden should be placed on sunny or semi-shaded locations, the lower area of a hillside is recommended (Rain-Garden Design and Implementation for Cansas Property Owners).

Another important factor regarding rain gardens is soil class and soil permeability. According to Díaz Iglesias (2013), the recommended soil combination is $50-60 \%$ of sand, $30-40 \%$ of loam and $5-10 \%$ of organic material. Hoffman and Orozco (2003) indicate a soil combination $-50 \%$ of sand, $20-30 \%$ of top soil, $5 \%$ of loam a $20-30 \%$ of organic material (leaf fall). Fresh mulch is top coat and it is important to use a layer of 0.05-0.07 meters of thickness of this material.

The shape of a garden can differ a lot. In most cases, rain gardens are formed into a 'bean shape'. According to the guide for Alabama Master Gardeners (BannermannConsidine), this shape is not necessary to use. However, there is a wide variety regarding the quality and the soil class, the depth of rain gardens, slopes and the size of rain gardens. The area depends on the size of the roofed areas which act as a water source and represent $1 / 3$ to $1 / 4$ of that roof; it varies between $9.3-27.8$ square meters (Dane County Lakes and Watershed Commission). There is another relation - the distance from the water source (roof) and the soil class. In this case, the guide for Alabama Master Gardeners (Bannermann - Considine) indicates 'size factor', which is multiplied by the size of collection area and as a result, there is a recommended size of a rain garden.

Laurenson and Arundell (2010) distinguish two categories of rain gardens - large rain gardens with the size of 30 square meters and more; and small rain gardens with the size of 1-2 square meters or less. For both sizes, it

Table 1 Size factor of rain gardens - distance from the water source under (9.14 meters)

\begin{tabular}{|l||c|c|c|}
\hline \multicolumn{1}{|c||}{ Soil class } & \multicolumn{3}{c|}{ Depth of rain garden (m) } \\
\cline { 2 - 4 } & $\mathbf{0 . 0 7 - 0 . 1 5}$ & $\mathbf{0 . 1 5 - 0 . 1 7}$ & $\mathbf{0 . 2 0}$ \\
\hline \hline \multirow{2}{*}{ Sand } & 0.19 & 0.15 & 0.08 \\
\hline Loam & 0.34 & 0.25 & 0.16 \\
\hline Clay & 0.43 & 0.32 & 0.20 \\
\hline
\end{tabular}

is important to meet the criterion of length to width ratio of $2: 1$. If the planting area of rain gardens exceeds 30 square meters, it is recommended to divide the area into various smaller parts.

Authors also differ in the setting of an optimal depth of rain gardens - the guide for Alabama (BannermannConsidine) indicates the depth of 0.10 to 0.20 meters, Natural Resources Conservation Service of USDA (2011) indicates the depth of 0.15-0.20 meters and the handbook for Cansas Property Owners indicates $0.10-0.30$ meters. Recommended slopes range between 12 and 15\% (RainGarden Design and Implementation for Cansas Property Owners, Natural Resources Conservation Service of USDA, 2011).

There are two possibilities how to construct the inlet of water into a rain garden. One of them is a direct way by spout pipes or sloped furrow. The other option is the underground inflow with outfall, reinforced with geotextile covered with gravel. The important part of a rain garden is the water outlet that acts as a spillway in the case of extreme storms. The outflow is placed above the maximum water level and in the period of exceeding saturation (heavy rainfall), the water is flowing out of the rain garden - it is necessary to take into account the spilling of water exceeding the area of rain garden during the design process.

In rain gardens, it is recommended to use local plant species because of their better adaptation to local natural conditions, especially water excess or water deficiency (Rain-Garden Design and Implementation for Cansas Property Owners). Apart from herbs, small shrubs or trees can be used as well. According to Hoffman and Orozco (2003), it is recommended to use three kinds of trees and three kinds of shrubs as the minimum to ensure a better biodiversity of a rain garden system. The planting area is divided into three zones - plants which tolerate water excess are located in the central part, plants tolerant to short-term inundation are located towards external part and plants preferring drier soils are planted in the outer parts (Díaz Iglesias, 2013).

The maintenance of a rain garden in the form of weed control is important, especially in the first two years of rain garden operation, till the plants are strong enough to compete. During the first weeks of the dry season, it is necessary to provide ordinary watering. Control and renewal of mulch is also important in spring and autumn. As for a perennial bed - control, cleaning and removal of dead organic material in spring are necessary to keep plants healthy and functional. It is prohibited to fertilise or to use chemical treatment. Maintenance of water inlet and water outlet is also of particular importance.

Table 2 Size factor of rain gardens - distance from water source above (9.14 meters)

\begin{tabular}{|l||c|}
\hline Soil class & All depths \\
\hline \hline Sand & 0.03 \\
\hline Loam & 0.06 \\
\hline Clay & 0.1 \\
\hline
\end{tabular}


List of plants suitable for rain gardens - Central European conditions:

Trees and Shrubs: Aesculusparviflora, Amelanchiersp., Aronia melancarpa, A. arbutifolia, Acer rubrum, Betula nigra, B. populifolia, Cornus racemosa, Hamamelis virginiana, Juniperus virginiana, Liquidambar styraciflua, Parthenocissus quinquefolia, Potentilla fruticosa, Quercus rubra, Salix sp., Sambucus sp., Thuja occidentalis, Viburnum opulus

Grasses: Carex sp., Deschampsia cespitosa, Miscanthus sp., Panicum virgatum

Perennials: Aster dumosus, A. ericoides, A. novae-angliae, Eupatorium maculatum, Helenium autumnale, Helianthus salicifolius, Heliopsis heliantoides, Hemerocalis sp., Chrysanthemum serotinum, Iris pseudacorus, I. spuria, Juncus effinus, J. ensifolius, Liatris spicata, Myosothis palustris, Physostegia virginiana

Definitely inappropriate for rain gardens: gramineous plants, Rubus armeniacus, Taraxacum officinale, Calystegia sepium, Ranunculus repens

\section{Rain gardens and methods of water management used worldwide}

Foreign countries have a different attitude towards water management from Slovakia. To illustrate some interesting existing projects, we mention the list below:

- Edinburgh Gardens Raingarden (2010-2012, author: GHD Pty Ltd.) - the park was built up to resolve drinkable water problems in recent years (landezine.com).

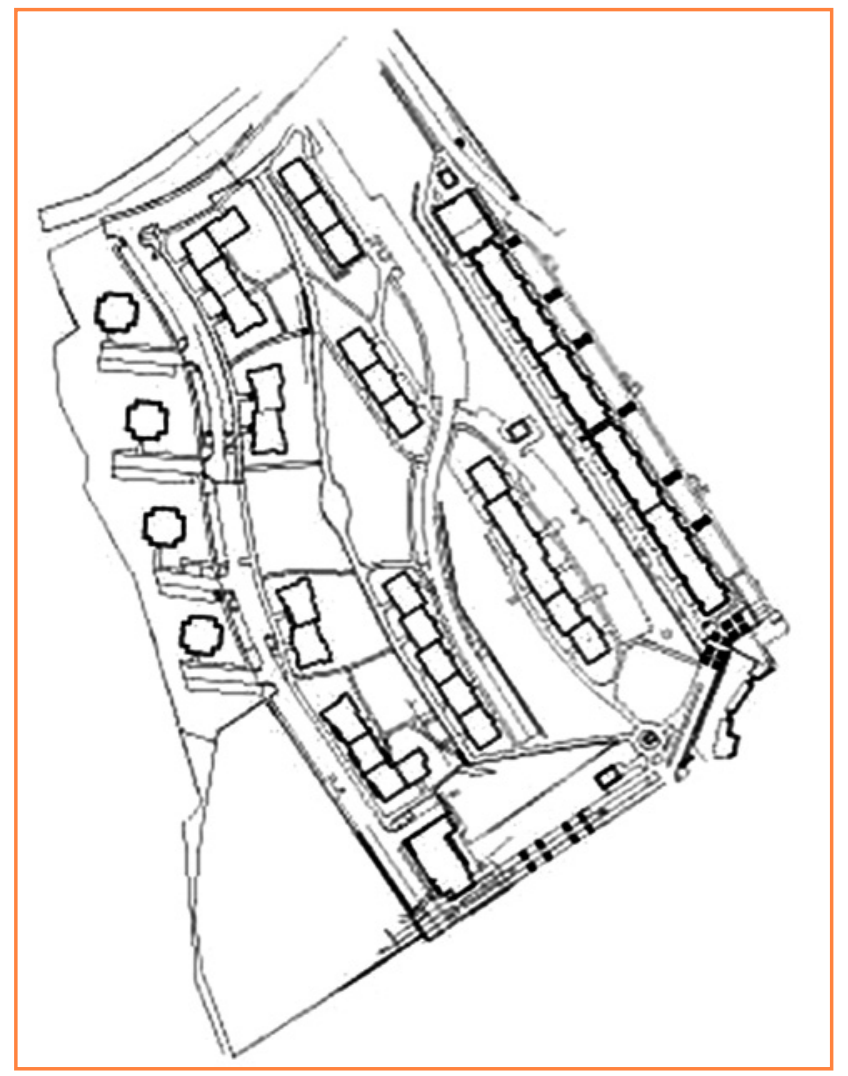

Figure 1 Location of rain gardens in the housing estate area
- EVA-Lanxmeer, Culemborg, The Netherlands (1999 - present, author: J. Eble, opMAAT/Arcadis/Hyco Verhaagen) - represents a project of a residential area for approximately 250 houses. In those places, there are infiltration pools, stormwater reservoirs, underground water channels, parking lots made of permeable materials, etc. (urban greenbluegrids.com).

- Rain gardens of the historical centre of Barranquilla, Columbia (author: OPUS) - the aim of the project is to improve the conditions of five historical squares. Revitalization fulfils the conditions of sustainable water management (opusestudio.com).

- Residential area Expo, Seattle, WA (author: Berger Partnership) - the rain gardens situated near the entrances to buildings are part of sustainable design (vireods.com).

- Rain gardens in Norpoint Park, Tacoma, USA (metro parkstacoma.org)

\section{Results and discussion}

The studied topic was applied to a study dedicated to revitalization of the public space in the housing estate Diely IV, Nitra in the form of rain gardens in the central part. Water management in this area is also applied to this study in the form of underground water reservoirs, permeable concrete in parking lots, vegetation, etc.

The rain garden is portrayed as a narrow line of terrain depression, which is situated near a pathway in the central part of the housing estate. The planting area is divided into three parts because of its dimensions - 100 square meters in total (RG 1-30 square meters, RG 2-30 square meters a RG 3-40 square meters - divided into two smaller rain gardens). The inner structure of the gardens includes three zones planted with groups of plants tolerant to soil moisture fluctuation (the border - plant tolerant to longterm drought, the central zone - plants tolerant to local soil wetness, the inner part of the rain garden - plant tolerant to long-term wet soils).

Location of the rain garden under the terrain modulation allows the natural water to flow in the rainy season. The shape of the planting area also contributes to a better absorption of water - the longer side is oriented to the ground slope. It

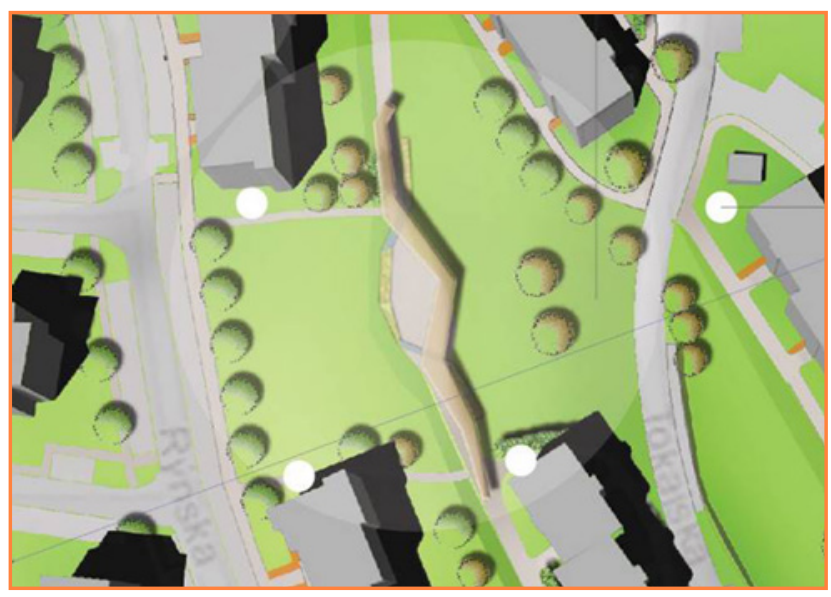

Figure 2 Rain gardens - part of the new project 


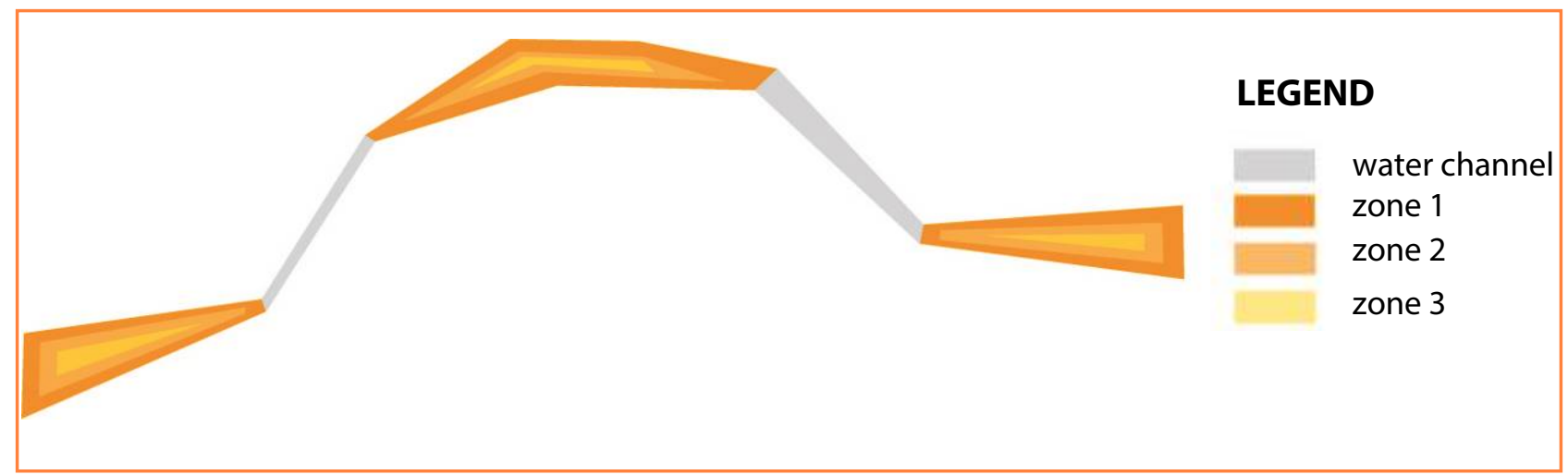

Figure 3 Planting concept of the rain garden - division into zones and application of plant mixtures

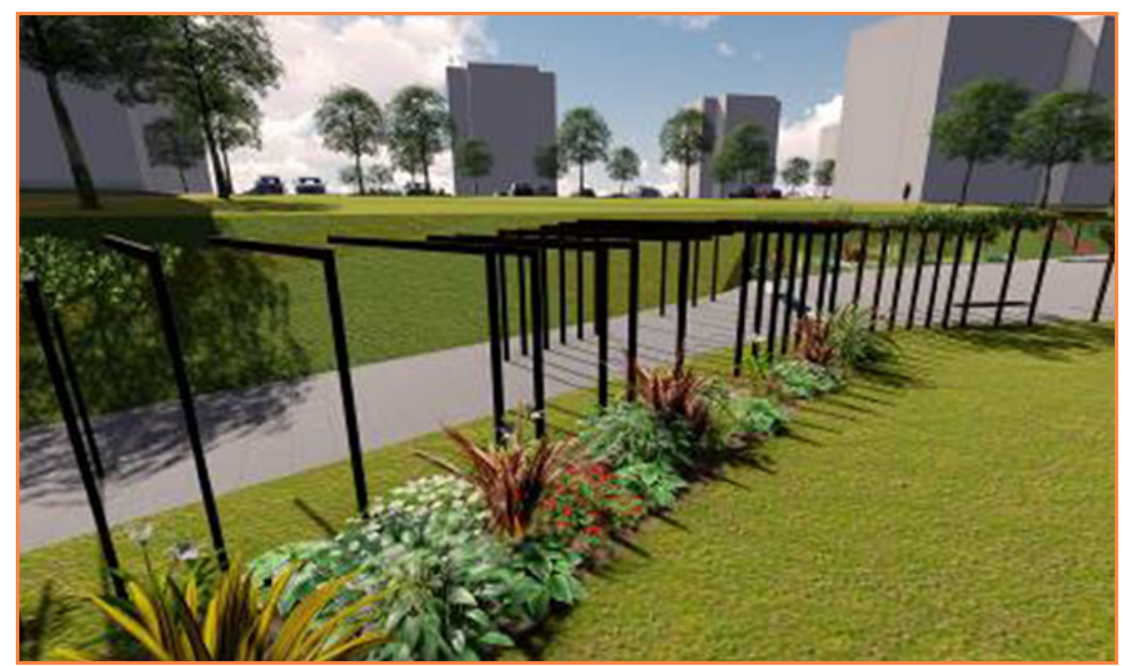

Figure 4

Visualization of the rain garden in the housing estate Diely, Nitra is also possible to connect the planting area with spouts using underground pipes.

Plants used in the rain garden should represent autochthonous and resistant species. Autochthonous plants are more tolerant to excess of water deficiency, because of their strong root system. The planting process is based on distributing the plants into three zones (each zone $=$ one plant mixture). Selected plant species are planted arbitrarily by their reference to the specific rain garden zone.

Landscape architecture focused on sustainable design in Central

Table 3 Proposed selection of rain garden plants

\begin{tabular}{|l||c|c|c|c|c|c|c|}
\hline No. & Mixture 1 - name & Height $(\mathbf{m})$ & Blooming time & RG1 pcs & RG2 pcs & RG3 pcs & Total pcs \\
\hline \hline $\mathbf{1}$ & Helenium autumnale & 1.20 & VIII-IX & 21 & 25 & 37 & 85 \\
\hline $\mathbf{2}$ & Liatris spicata'Kobold' $^{\prime}$ & 0.50 & VII-VIII & 51 & 55 & 61 & 167 \\
\hline $\mathbf{3}$ & Iris spuria & 0.80 & VI-IX & 31 & 35 & 41 & 109 \\
\hline $\mathbf{4}$ & Miscanthus sinensis 'Morning Light' & 1.50 & IX-X & 3 & 3 & 9 & 15 \\
\hline \hline No. & Mixture 2 - name & Height (m) & Blooming time & RG1 pcs & RG2 pcs & RG3 pcs & Total pcs \\
\hline \hline $\mathbf{5}$ & Deschampsia cespitosa & 1.00 & VI-VIII & 7 & 9 & 9 & 27 \\
\hline $\mathbf{6}$ & Eupatorium maculatum 'Gateway' & 1.50 & VI-IX & 9 & 11 & 13 & 33 \\
\hline $\mathbf{7}$ & Heliopsis heliantoides & 1.00 & VI-VIII & 13 & 11 & 15 & 41 \\
\hline $\mathbf{8}$ & Physostegia virginiana 'Alba' & 1.00 & VII-IX & 15 & 11 & 15 & 41 \\
\hline $\mathbf{9}$ & Aster dumosus 'Augenweide' & 0.40 & IX-XI & 21 & 15 & 17 & 65 \\
\hline $\mathbf{1 0}$ & Aster novae-angliae'Herbstschnee' & 1.20 & VIII-X & 9 & 9 & 12 & 30 \\
\hline \hline No. & Mixture 3 - name & Height (m) & Blooming time & RG1 pcs & RG2 pcs & RG3 pcs & Total pcs \\
\hline \hline $\mathbf{1 1}$ & Juncus effinus & 0.30 & VII-VIII & 9 & 5 & 9 & 23 \\
\hline $\mathbf{1 2}$ & Juncus ensifolius & 0.30 & VII-VIII & 5 & 5 & 9 & 19 \\
\hline $\mathbf{1 3}$ & Iris pseudacorus & 1.50 & VI-IX & 13 & 9 & 27 & 51 \\
\hline Plants total pcs/rain garden & & & 207 & 203 & 274 & 683 \\
\hline
\end{tabular}


Europe is still behind the developed countries. The aim of this paper is to provide an overview of possibilities and importance of new trends in landscaping, raising thereby the public awareness. The elaborated issue of rain gardens can significantly contribute to green infrastructure improvement, which leads to sustainable urban landscapes that are more resistant to climate change as stated by Tóth and Feriancová (2014). The studied topic was applied to the project proposal for rain gardens in the housing estate Diely IV, Nitra. It is paradoxical that there has been no attention paid to rain gardens so far, considering the simplicity of their implementation and subsequent maintenance.

\section{Conclusion}

Application of ecological approaches in landscape architecture or revitalisation process is one of the main steps in creating urban areas without environmental deterioration, increased financial demands caused by necessary maintenance and sociological effect on new generations. Rain gardens represent a simple solution, which is also easily incorporated into plans and their environmental impact helps to keep the balance of the environment. Rain gardens are an element of water management - they safely drain the rain water. Furthermore, they form a new bio-center in urban areas, affect the microclimate, and plants positively influence the aesthetics of the environment in the blooming period.

\section{Acknowledgement}

This paper is one of the outcomes of the national project KEGA No. 001SPU-4/2014 Green Infrastructure and Urban Agriculture of the Ministry of Education, Science, Research and Sport of the Slovak Republic.

\section{References}

BANNERMAN, R. - CONSIDINE, E. 2015. Rain Garden Design for Home Owners - A guide compiled for Alabama Master Gardeners. University of Wisconsin. [online]. [cit. 16. 10. 2015]. Available at: <http://www.slideshare.net/pd81xz/zwx1>

Dane County Lakes and Watershed Commission: How to build a rain garden $-A$ beautiful addition to your yard that helps protect our water resources! [online]. [cit. 7. 9. 2015]. Available at: <www. danewaters.com/pdf/HowToBuildaGarden.pdf>

DÍAZIGLESIAS, M. I. 2013. Jardines de lluvia. [online]. [cit. 31. 1. 2015]. Available at: <http://www.cfeaguisamo.org/webcfea/images/ documentacion_tecnica/xornadas_tecnicas/raingardens2013/ RAIN\%20GARDENS_1.pdf>

EVA-Lanxmeer, Culemborg. The Netherlands. [online]. [cit. 10. 4. 2015]. Available at: <http://www.urbangreenbluegrids.com/ projects/eva-lanxmeer-results/>

FUSKA, J. 2009. Constructed wetlands and suitable wetland plants. In LI. Georgikon napok : Kivonat Kötet. Keszthely: Pannon Egyetem Georgikon Kar, 2009, p. 315-319. ISBN 978-963-9639-34-8.
HOFFMAN, S. - OROZCO,W. 2003. Rain gardens. 6s. ECOL 8720. 2003. [online]. [cit. 10. 9. 2015]. Available at: <http://www.slideshare.net/ pd81xz/zwx21?qid=bcd18ea9-3d08-46b2-864c-1b678e9f33e5\&v= default\&b=\&from_search $=1>$

HRAŠKO et al. 1993. [online]. $1: 400$ 000. Soil map of Slovakia. National agriculture and food centre. Soil portal. [cit. 25. 2. 2015]. Available at: <www.podnemapy.sk/portal/prave_menu/podna_ mapa/podna_mapa.aspx>

LANDEZINE. Edinburgh Gardens Raingarden. [online]. [cit. 10. 4. 2015] Available at: <http://landezine.com/index.php/2012/10/ edinburgh-gardens-raingarden-by-ghd-pty-ltd/>

LAURENSON, M. - ARUNDELL, P 2010. Sustainable Gardens - Rain Gardens. [online]. [cit. 5. 10. 2015]. Available at: <http://www.ata. org.au/wp-content/uploads/madeline-laurenson-talk.pdf>.

Natural Resources Conservation Service of USDA: Los Jardines de Lluvia. 2011. [online]. [cit. 13. 10. 2015] Available at: <http://www. nrcs.usda.gov/Internet/FSE_DOCUMENTS/nrcs142p2_011368. pdf>

NOVOTNY, V. - OLEM, H. 1994. Water Quality: Prevention, Identification, and Management of Diffuse Pollution. Van Nostrand Reinhold, New York, 1054 pp.

Rain-Garden Design and Implementation for Cansas Property Owners. [online]. [cit. 5. 10. 2015]. Available at: http://faculty.capd. ksu.edu/lskab/KSU-LARCP_Rain-Garden-Guidebook-Irs.pdf>

Rain gardens in Norpoint Park, Tacoma, USA. [online]. [cit. 10. 4. 2015]. Available at: <http://www.metroparkstacoma.org/ norpoint-park/>

Rain gardens of historical center of Barranquilla, [online]. [cit. 10. 4. 2015]. Available at: <http://www.opusestudio.com/index.php/es/ proyectos/renovacion-centro-historicobarranquilla/>

RainWise Program. [online]. [cit. 11. 4. 2015]. Available at: <http:// www.seattle.gov/util/MyServices/DrainageSewer/Projects/ GreenStormwaterInfrastructure/RainWise/index.htm>

Residentail areal Expo, Seattle, WA. [online]. [cit. 10. 4. 2015]. Available at: <http://vireods.com/multi-family/>

STIFFLER, L. 2013. Are Rain Gardens Mini Toxic Cleanup Sites? Partnership for Water Sustainability. [online]. [cit. 6. 10. 2015]. Available at: <http://waterbucket.ca/gi/2013/02/02/ are-rain-gardens-mini-toxic-cleanup-sites/>

TÓTH, A. - HALAJOVÁ, D. - HALAJ, P. 2015. Green Infrastructure: A Strategic Tool for Climate Change Mitigation in Urban Environments. In Journal of International Scientific Publications: Ecology \& Safety, vol. 9, pp. 132-138. ISSN 1314-7234.

TÓTH, A. - FERIANCOVÁ, L. 2014. By Improvement of the Green Infrastructure towards Sustainable Landscapes and Resilient Environments. In: G20 Youth Forum 2014 Conference Proceedings, Garmisch-Partenkirchen, Germany. Genève: G8\&G20 Alumni Association, 2014, pp. 405-410. 695 p. ISSN 2297-0134.

12000 rain gardens in Puget Sound. [online]. [cit. 11. 4. 2015]. Available at: <http://www.12000 raingardens.org/> 